\title{
Papio anubis
}

National Cancer Institute

\section{Source}

National Cancer Institute. Papio anubis. NCI Thesaurus. Code C161025.

The baboon species, Papio anubis. 